\title{
PRELIMINARY RESULTS ON GENETIC DIVERSITY IN EGYPTIAN CATTLE USING MICROSATELLITE MARKERS
}

\author{
M. S. Hassanane ${ }^{1}$, H. M. El-Ashmaoui ${ }^{1}$, S. Abd El-Baset ${ }^{2}$, M.M. S. \\ Mabrouk $^{3}$ and Z. G. Abdel-Hameid ${ }^{1}$ \\ 1- Cell Biology Department, National Research Center, Dokki, Giza, Egypt, \\ 2-Department of Zoology, Faculty of Science (Girls Branch), Al- Azhar \\ University, 3- Department of Animal Production, Faculty of Agriculture, Al- Azhar \\ University
}

\section{SUMMARY}

To study the genetic diversity of the Egyptian native cattle, a total of 67 cattle representing five populations were genotyped for 4 microsatellite markers (ETH225, ETH152, HEL09 and INRA05). The numbers of observed alleles all over the populations studied were: 12, 8, 12 and 4 respectively. Heterozygosity and Wright's F-statistics (FIS, FST, and FIT) were calculated to determine the genetic variation in these populations. High values of observed heterozygosities were noticed in all the populations, it were in the range of 0.719 (Beni Souif) for the marker INRA05 to 0.933 (Beni Souif) for the marker ETH 225. All the FIS values were below the zero, meaning the absence of inbreeding within the populations under study. Depending on the genetic distances a dendrogram showing the genetic relationship among the different populations was prepared. High values of the average gene diversity were noticed, for all the markers and all the populations, it ranged from 0.765 to 0.866 with an overall mean 0.833. Values of gene flow or migration between populations were high meaning that migration and admixture could have taken place between these populations. The study proved that Egyptian cattle are only one breed with different populations.

\section{Keywords: Egyptian, cattle, microsatellite, diversity}

\section{INTRODUCTION}

In the recent years, rapid advanced development in the molecular genetic techniques have made it possible to identify differences between individuals at the DNA level and using genomic variation for the genetic improvement of livestock. The assessment of genetic variation is especially important in highly specialized livestock breeds since the use of assisted reproduction techniques, such as artificial insemination and embryo transfer can rapidly reduce the genetic variation of the population. Molecular methods have provided new markers for the study of genetic variation, even to the level of analysis at the DNA sequences itself. Molecular markers have been widely used to assess this variability since they provide information on every region of the genome. Among these molecular markers,

Issued by The Egyptian Society of Animal Production 
microsatellites (highly polymorphic simple sequence repeats) are currently the most widely used molecular markers. Microsatellites have been used in studying genetic variability in all domestic species either animals, birds and even fish. Genetic variability within and among populations is often of importance and may contribute to the selection and preservation of genetic resources.

Microsatellites are a sub-class of non-coding DNA, which is tandem repeated. They mainly constitute double or triple short nucleotides, and was discovered in bovine by Fries et al. (1990).

Food and Agricultural Organization of the United Nation (FAO, 1993) reported that the Egyptian cattle had eight breeds: two of them were disappeared or diminished (African aurochs and Hamitic longhorn) while the other six cattle breeds are Baladi, Domiette, Egyptian, Maryuti, Menufi, and Saidi, are still present (www.Fao.org/Dad-Is). In contrast, the Egyptian animal breeders usually mention that the Egyptian cattle are only one cattle breed called Baladi. Local populations may have different names, but without apparent differences in phenotype; a change in phenotype may occur without change in name, or all population may have just one name and be phenotypically similar.

The Egyptian Baladi cattle are draft medium sized animals. Its color ranges from brown to black or pied. Approximately $30 \%$ are polled. Due to the low milk productivity of these animals, it is neglected for a long time and its genetic improvement took place only through hybridization with foreign breeds (Morsy, 1980).

The local Egyptian cattle individuals have suffered a substantial decrease in population size, which might cause high levels of inbreeding resulting in inbreeding depression and increasing the risk of breed extinction. The conservation of genetic variation found in these minor livestock individuals is a growing worldwide concern due to the increasing risk of breed loss.

The aim of the present study was to use some microsatellites genetic markers to study the genetic diversity in the Egyptian native cattle. Additional to answer the question: Do the Egyptian cattle belong to different breeds or only one breed? If it is proved that this cattle belong to different breeds what is the genetic relationships between them. The purity of the breeds could be also measured if it is proved that they are different breeds.

\section{MATERIALS AND METHODS}

\section{Blood samples}

Sixty seven blood samples were colleted from 5 different regions representing the five suspected breeds under-study. The samples were collected from unrelated animals.

\begin{tabular}{lcc}
\multicolumn{2}{c}{ The details of these samples are as follows: } \\
\hline Area & Suspected breed & $\begin{array}{c}\text { No. of } \\
\text { samples }\end{array}$ \\
\hline Cairo and Giza & Baladi & 15 \\
Domiatt & Domiette & 15 \\
Alexandria & Marioti & 13 \\
Middle Delta & Menoufi & 15 \\
Beni Souif & Saidi & 9 \\
\hline
\end{tabular}




\section{DNA extraction, PCR and electrophoresis}

Genomic DNA extraction was extracted from blood samples using a standard phenol: chloroform extraction method (Sambrook et al., 1989). Four microsatellites markers were used and were chosen according to a joint meeting recommendation, between the International Society of animal genetics (ISAG) and FAO (1998), for genetic diversity studies. Details of these markers are in the following table:

\begin{tabular}{|c|c|c|c|}
\hline $\begin{array}{c}\text { Marker } \\
\text { name }\end{array}$ & $\begin{array}{c}\text { Chromosomal } \\
\text { location }\end{array}$ & Primer sequence & Reference \\
\hline ETH152 & D5S1 & $\begin{array}{l}\text { TAC TCG TAG GGC AGG CTG CCT G } \\
\text { GAG ACC TCA GGG TTG GTG ATC AG }\end{array}$ & $\begin{array}{l}\text { Steffen et al., } \\
1993\end{array}$ \\
\hline ETH225 & D9S1 & $\begin{array}{l}\text { GAT CAC CTT GCC ACT ATT TCC T } \\
\text { ACA TGA CAG CCA GCT GCT ACT }\end{array}$ & $\begin{array}{l}\text { Steffen et al., } \\
1993\end{array}$ \\
\hline INRA05 & D12S4 & $\begin{array}{l}\text { CAATCTGCATGAAGTATAAATAT } \\
\text { CTTCAGGCATACCCTACACC }\end{array}$ & $\begin{array}{l}\text { Vaiman et al., } \\
1994\end{array}$ \\
\hline HEL09 & D8S4 & $\begin{array}{l}\text { CCCATTCAGTCTTCAGAGGT } \\
\text { CACATCCATGTTCTCACCAC }\end{array}$ & $\begin{array}{l}\text { Kaukinen and } \\
\text { Varvio, } 1993\end{array}$ \\
\hline
\end{tabular}

Polymerase chain reaction (PCR) was carried out on $50 \mathrm{ng}$ of genomic DNA in a $25 \mu \mathrm{l}$ reaction of $50 \mathrm{mM} \mathrm{KCl}, 10 \mathrm{mM}$ Tris- $\mathrm{HCl}(\mathrm{pH} 8.3), 200 \mu \mathrm{M}$ dNTP, $1.5 \mathrm{mM}$ $\mathrm{MgCl}_{2}, 1 \mathrm{mM}$ tetra-ammonium-chloride, $0.1 \%$ Triton X-100, 0.01\% gelatin, $4.5 \mathrm{pmol}$ of each primer and $0.25 \mathrm{U}$ Taq DNA polymerase. The standard PCR run cycle was usually as: Primary denaturation: $95^{\circ} \mathrm{C}$ for $3 \mathrm{~min}$. then: 35 cycles as: $95^{\circ} \mathrm{C}$ for 15 sec.; $55-60^{\circ} \mathrm{C}$ for $30-60 \mathrm{sec}$; $72^{\circ} \mathrm{C}$ for $30 \mathrm{sec}$. Final extension: $72^{\circ} \mathrm{C}$ for $5 \mathrm{~min}$., Storage: $15^{\circ} \mathrm{C}$ forever. The success of the PCR was detected on $2 \%$ agarose after running in horizontal electrophoresis set and staining with ethidium bromide. For optimization the PCR the temperature and the time of the annealing temperature were changed.

The products of the successful PCR were characterized under denaturing conditions on $12 \%$ polyacrylamide vertical electrophoresis (Sambrook et al., 1989).

After the end of the run, the gel was stained in an ethidium bromide solution $(0.5 \mu \mathrm{g}$ $/ \mathrm{ml}$ TBE buffer). The gel image was captured electronically using Biometra Gel documentation system. The allele sizes were determined using free software named Lab. image V2.7. It is dispersed free from Proland company (Germany), from the internet through the web page: http://www.labimaging.com/servlet/engine/home /start.html

\section{Statistical analysis of the results}

POPGENE software package (Yeh et al., 1999) was used to calculate allele frequencies, observed number of alleles, effective number of alleles (Kimura and Crow, 1964), observed (Ho) and expected (He) heterozygosity at each locus in the five populations under study. Polymorphism information content (PIC) value for each locus was calculated by using the method described by Bostein et al. (1980). Pairwise alleles sharing were calculated manually from the raw results.

Using the variance-base method of Weir and Cockerham (1984), population differentiation by $F$-statistics was computed using FSTAT version 2.9.3.2 computer 
program (Goudet, 2002). Mean a standard deviations of the $F$-statistics program, F .f, that are analogue to Wright's (1951 \& 1978) Fis and Fst, were obtained across breeds by the Jackknifing procedure over loci (Weir, 1990). The extent of global inbreeding was further studied with the same software by estimated Fis value.

The effect of migration and gene flow on the genetic structure of the analyzed populations was estimated between each pair of populations according to an island model under neutrality and negligible mutation (Slatkin, 1985). Genetic distances among populations were estimated using (Ds) standard genetic distance of Nei (1972) and the DA distance of Nei et al. (1983).

\section{RESULTS AND DISCUSSION}

This is the first study performed in Egypt on the genetic diversity of different Baladi cattle populations raised in Egypt. The results provide an indication of the feasibility of the methodology as well as information on differentiation between and within the five Baladi cattle populations studied

In the present study, the four microsatellites analyzed were polymorphic. The microsatellite ETH 152 showed eight alleles with a size range from 191 to $219 \mathrm{bp}$. The microsatellite ETH 225 showed twelve alleles with a size range from 140 to 176 bp. The microsatellite INRA05 showed four alleles with a size range from 139 to161 bp. The microsatellite HEL09 showed eight alleles with a size range from 149 to 191 bp.

Due to the large numbers of alleles observed for these markers, they could be fruitfully used in paternity tests. Moreover, they can be employed in further researches on quantitative trait loci (QTL) detection and subsequently marker assisted selection (MAS).

Histogram 1. is showing the he allelic sizes and frequencies of different markers observed in all the populations studied: (a: ETH225; b: ETH152; c: INRA04 and d: HEL09).

The average allele number was 9 alleles; this number is higher than the range of 6-9 alleles, which was reported in many cattle breeds from Europe, West Africa and Brazil (McHugh et al., 1998; Lubieniecka et al., 2001; Machado et al., 2003 and Ibeagha-Awemu et al., 2004). This is an indication for the high ratio of heterozygosity which arises from the absence of selection or organized breeding programs for the Egyptian cattle.

The results regarding the numbers of shared alleles between the different populations under study are presented in Table: 1 . 

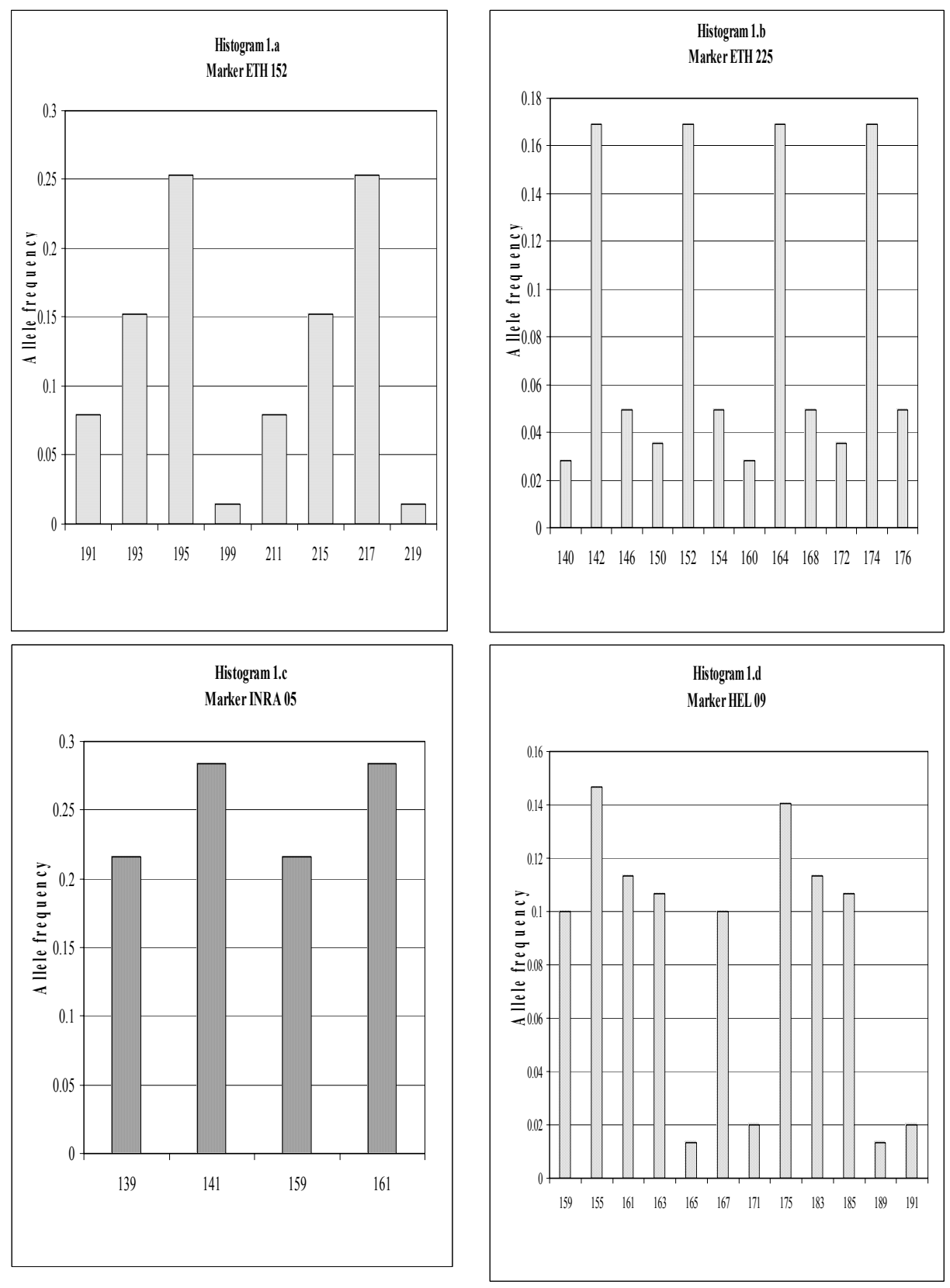
Table 1. Number of shared alleles between the different populations under study

\begin{tabular}{lcccc}
\hline \multicolumn{1}{c}{ Population } & \multicolumn{4}{c}{ Marker } \\
\cline { 2 - 5 } & ETH152 & ETH225 & INRA 05 & HEL 09 \\
\hline Beni Souif \& Cairo & 6 & 8 & 4 & 6 \\
Beni Souif \& Alexandria & 6 & 8 & 4 & 6 \\
Beni Souif \& Middle delta & 4 & 8 & 4 & 6 \\
Beni Souif \& Domiatt & 6 & 6 & 4 & 8 \\
Cairo \& Alexandria & 6 & 10 & 4 & 8 \\
Cairo \& Middle delta & 4 & 10 & 4 & 10 \\
Cairo \& Domiatt & 6 & 8 & 4 & 10 \\
Alexandria \& Middle delta & 4 & 10 & 4 & 8 \\
Alexandria \& Domiatt & 6 & 8 & 4 & 8 \\
Middle delta \& Domiatt & 4 & 8 & 4 & 10 \\
All the population & 4 & 6 & 4 & 6 \\
\hline
\end{tabular}

Except for the marker INRA05 which gave only 4 alleles present in all the populations, the allele sharing results did not show any obvious results, unique or specific alleles for specific region or population.

Concerning the measuring of genetic variation for each population (observed and effective number of alleles) observed and expected heterozygosity and polymorphism information content (PIC) are presented in Table (2).

In all the populations under study, there were not any individuals carrying homozygous alleles, therefore all the observed heterozygosity values for the alleles in the different populations under study were equal 1.

Accordingly the values of the expected heterozygosity were very high for all the markers and populations under study. The values of observed heterozygosity were higher than the expected heterozygosity indicates much of variability. The lowest value of heterozygosity was 0.719 and observed for the INRA 05 marker in Beni Souif region, while the greatest value was 0.933 and observed for the marker ETH225 in Beni Souif region also. The difference between the observed and expected values (chi- square) was highly significant at $p<0.01$ for all the markers in all the populations studied.

The PIC is an expected heterozygosity derived from allele frequencies in random mating populations. PIC is an indicator of how many alleles a certain marker has how much these alleles divided evenly. For example if a marker has many alleles but only one of them is frequent, the PIC will be low. PIC values were generally high and varied from 0.716 (INRA 05) in Delta to 0.883 (HEL 09) in Domiatt.

All cattle populations presented very high polymorphism of DNA. This is testified by the considerable number of alleles identified, the high mean number of alleles and the high degree of observed (Ho) and expected (He) heterozygosity. 
Table 2. Microsatellite alleles (No, observed number of alleles; Ne, effective number of alleles), heterozygosity (Ho, observed; He, expected) and polymorphism information content (PIC) at each locus in the different populations under study

\begin{tabular}{|c|c|c|c|c|c|c|c|}
\hline \multicolumn{3}{|c|}{$\begin{array}{c}\text { Locus } \\
\text { Population }\end{array}$} & INRA05 & ETH225 & ETH152 & HEL09 & Mean \\
\hline \multirow{5}{*}{ Beni Souif } & \multirow{2}{*}{ Alleles } & No & 4 & 10 & 6 & 8 & 7.00 \\
\hline & & $\mathrm{Ne}$ & 3.951 & 8.0 & 4.92 & 5.22 & 5.52 \\
\hline & \multirow{2}{*}{ Het. } & Ho & 1 & 1 & 1 & 1 & 1.0 \\
\hline & & $\mathrm{He}$ & 0.7908 & 0.933 & 0.850 & 0.8562 & 0.858 \\
\hline & \multicolumn{2}{|c|}{ PIC } & 0.723 & 0.868 & 0.781 & 0.796 & 0.792 \\
\hline \multirow{5}{*}{ Alexandria } & \multirow{2}{*}{ Alleles } & No & 4 & 12 & 8 & 8 & 8.00 \\
\hline & & $\mathrm{Ne}$ & 3.976 & 7.19 & 6.377 & 5.929 & 5.868 \\
\hline & \multirow{2}{*}{ Het. } & Ho & 1 & 1 & 1 & 1 & 1.0 \\
\hline & & $\mathrm{He}$ & 0.778 & 0.895 & 0.876 & 0.864 & 0.854 \\
\hline & \multicolumn{2}{|c|}{ PIC } & 0.725 & 0.854 & 0.821 & 0.820 & 0.805 \\
\hline \multirow{5}{*}{ Cairo } & \multirow{2}{*}{ Alleles } & No & 4 & 10 & 6 & 10 & 7.50 \\
\hline & & $\mathrm{Ne}$ & 3.982 & 7.627 & 4.83 & 8.526 & 6.241 \\
\hline & \multirow{2}{*}{ Het. } & Ho & 1 & 1 & 1 & 1 & 1.0 \\
\hline & & $\mathrm{He}$ & 0.774 & 0.898 & 0.818 & 0.907 & 0.850 \\
\hline & \multicolumn{2}{|c|}{ PIC } & 0.725 & 0.861 & 0.778 & 0.877 & 0.810 \\
\hline \multirow{5}{*}{ Delta } & \multirow{2}{*}{ Alleles } & No & 4 & 10 & 4 & 10 & 7.00 \\
\hline & & $\mathrm{Ne}$ & 3.846 & 5.263 & 3.938 & 8.307 & 5.338 \\
\hline & \multirow{2}{*}{ Het. } & Ho & 1 & 1 & 1 & 1 & 1.0 \\
\hline & & $\mathrm{He}$ & 0.765 & 0.830 & 0.770 & 0.905 & 0.817 \\
\hline & \multicolumn{2}{|c|}{ PIC } & 0.716 & 0.797 & 0.722 & 0.873 & 0.777 \\
\hline \multirow{5}{*}{ Domiatt } & \multirow{2}{*}{ Alleles } & No & 4 & 8 & 6 & 12 & 7.5 \\
\hline & & $\mathrm{Ne}$ & 3.284 & 5.696 & 4.267 & 8.892 & 5.535 \\
\hline & \multirow{2}{*}{ Het. } & Ho & 1 & 1 & 1 & 1 & 1.0 \\
\hline & & $\mathrm{He}$ & 0.719 & 0.853 & 0.790 & 0.892 & 0.813 \\
\hline & \multicolumn{2}{|c|}{ PIC } & 0.667 & 0.813 & 0.747 & 0.883 & 0.778 \\
\hline
\end{tabular}

Concerning the results of the gene diversity for the four markers in the five populations studied, the results are presented in Table 3.

Table 3. Average gene diversity

\begin{tabular}{lccccc}
\hline \multicolumn{1}{c}{ Area } & \multicolumn{3}{c}{ Marker } & \multirow{2}{*}{$\begin{array}{c}\text { Mean } \\
\text { estimate }\end{array}$} \\
\cline { 1 - 4 } & ETH 152 & ETH 225 & INRA 05 & HEL 09 & 0.845 \\
Cairo area & 0.813 & 0.895 & 0.767 & 0.905 & 0.847 \\
Beni Souif & 0.839 & 0.929 & 0.778 & 0.847 & 0.848 \\
Middle delta & 0.763 & 0.826 & 0.757 & 0.902 & 0.817 \\
Alexandria & 0.872 & 0.891 & 0.769 & 0.859 & 0.847 \\
Domiatt & 0.783 & 0.848 & 0.710 & 0.912 & 0.813 \\
Total the & 0.813 & 0.877 & 0.756 & 0.886 & 0.833 \\
population & & & & & \\
\hline
\end{tabular}


The average gene diversity over all loci were 0.833 , while for individual loci the average gene diversity ranged between 0.710 (INRA 05) and 0.929 (ETH225). Since the marker INRA05 had only four alleles, the lowest values of gene diversity were noticed for it.

As expected, the microsatellite loci showed very high level of genetic diversity, (high values for the average gene diversity were noticed for all the markers and all the populations studied) within an average within population gene diversity ranged from 0.756 (INRA05) to 0.866 (HEL09), with an overall mean 0.833 . This value is almost similar to the previously reported by Loftus et al., (2002), which was 0.78 during their study concerning the identification of zebu alleles in some cattle breeds including Egyptian cattle. There was a significant positive relationship between averages within population gene diversity for each locus.

The relatively low value of the average gene diversity for the marker INRA05, when compared with the other markers could be explained by the low number of alleles observed for that marker. Moioli et al. (2001) noticed similar results during studying the genetic diversity between the Egyptian, Italian and Greek buffalo using microsatellite markers.

To assess genetic differentiation within the populations, Fis is a measure of the within population heterozygote defect (inbreeding). Table (4) shows within the populations inbreeding estimates $\{$ Fixation index statistics $($ FIS $=f$ ) $\}$ in the populations under study.

Table 4. Inbreeding estimates (FIS $=f$ ) within populations under study

\begin{tabular}{lccccc}
\hline \multicolumn{1}{c}{ Locus } & \multicolumn{5}{c}{ Area } \\
\hline & Cairo & Beni Souif & $\begin{array}{c}\text { Middle } \\
\text { delta }\end{array}$ & Alexandria & Domiatt \\
\hline ETH 152 & -0.231 & -0.191 & -0.311 & -0.147 & -0.277 \\
ETH 225 & -0.117 & -0.077 & -0.210 & -0.122 & -0.180 \\
INRA 5 & -0.304 & -0.286 & -0.321 & -0.300 & -0.409 \\
HEL9 & -0.105 & -0.180 & -0.109 & -0.164 & -0.097 \\
Mean Estimates & -0.184 & -0.179 & -0.232 & -0.180 & -0.230 \\
\hline
\end{tabular}

Looking at the table in general, it is noticed that all the inbreeding values were negative and below the zero. These values according to animal breeders should be considered zero, meaning the complete absence of inbreeding within the populations under study.

In contrast, Table 5 shows the inbreeding rates between sub-samples (populations) under study.

Table 5. Inbreeding rates between the populations under study

\begin{tabular}{cccccc}
\hline Area & Beni Souif & Alexandria & Cairo & $\begin{array}{c}\text { Middle } \\
\text { Delta }\end{array}$ & Domiatt \\
\hline Beni Souif & -------- & 0.000 & 0.007 & 0.0481 & 0.031 \\
Alexandria & 0.000 & ------- & -0.011 & 0.021 & 0.003 \\
Cairo area & 0.007 & -0.011 & -------- & -0.002 & -0.009 \\
Middle Delta & 0.048 & 0.021 & -0.002 & -------- & -0.004 \\
Domiatt & 0.031 & 0.003 & -0.009 & -0.004 & ----- \\
\hline
\end{tabular}


The results of this table is showing also either negative values or very low values and should be also considered zero, indicating the absence of inbreeding between the populations under study.

Table (6) indicates pair-wise values of genetic differentiation between the populations measured by fixation index (Fst), which varies between zero (meaning no genetic differentiation) and one (meaning complete genetic differentiation). The observed (Fst) is usually much smaller than 1.To help interpreting (Fst), Wright (1978) divided the value of (Fst) into four intervals: (1) from 0 to 0.05 , indicating little genetic differentiation; (2) from 0.05 to 0.15 , indicating moderate genetic differentiation; (3) from 0.15 to 0.25 , indicating great genetic differentiation; (4) from 0.25 to 1 , indicating very great genetic differentiation.

To quantify the effects of populations of migration on the genetic structure and gene flow was estimated by converting Fst to amount of gene flow $(\mathrm{Nm}) . \mathrm{Nm}$ indicates the average number of effective migrants exchanged per generation.

Table 6. FST (Fisher statistics) estimate (below diagonal) and effective migration rate $(\mathrm{Nm})$ (above diagonal) $(\mathrm{FST}=1 / 4 \mathrm{~N} \mathrm{m+1)}($ Wright, 1951)

\begin{tabular}{cccccc}
\hline & Beni Souif & Alexandria & Cairo & $\begin{array}{c}\text { Middle } \\
\text { delta }\end{array}$ & Domiatt \\
\hline Beni Souif & $* * * *$ & 57.889 & 34.432 & 5.173 & 7.920 \\
Alexandria & 0.0043 & $* * * *$ & -22.977 & 13.190 & 249.75 \\
Cairo & 0.0072 & -0.011 & $* * * *$ & -76.007 & -29.319 \\
Middle Delta & 0.0461 & 0.0186 & -0.0033 & $* * * *$ & -83.583 \\
Domiatt & 0.0316 & 0.001 & -0.0086 & -0.003 & $* * * *$ \\
\hline
\end{tabular}

The lowest degree of genetic differentiation between all populations was further supported by relatively the high level of gene flow between these populations. The higher value of gene flow observed between Domiatt and Alexandria indicated a possible coastal migration between the two areas in the past, the lower value of gene flow observed between Domiatt and Middle delta. .

Concerning the gene flow $(\mathrm{Nm})$, it was estimated using the equation:

Gene flow estimated from $\mathrm{Nm}=0.25(1-\mathrm{Fst}) /$ Fst.

The results of the gene flow for the 4 markers studied were: $20.409 ; 7.675 ; 7.755$ and 8.502 for the markers: INRA 05; ETH225; ETH152 and HEL 09 respectively with an average value of 11.085. This average value is higher than that reported in the European cattle breeds which varies from 4.37-8.35 (Loftus et al., 1999; Edwards et al., 2000 and Canon et al., 2001).

The high value obtained in our population may be due to two main reasons: the first is the marker INRA05 which has only four alleles and subsequently increases the value, secondly is the low number of markers studied. The gene flow may be a reason for increasing the heterozygosity. When individuals move into a population they may bring in alleles not already present in that population or in frequencies that differ from the allele frequencies of that population.

It is noticed that the gene flow value is correlated contrary with the number of the alleles observed in the population; the biggest value for gene flow (20.409) was for the marker INRA05 which has only four alleles. In contrast the other markers with more alleles, its gene flow values were lower (between 7.675 8.502). 
Estimation of Nei's standard genetic distances (Ds) and assumed mutation rates of microsatellites loci $(\alpha)$ were used to estimate the time of divergence $(t$, in generations) Where,

$$
\mathrm{Ds}=2 \alpha \mathrm{t} \text {. }
$$

The Ds method described by Nei (1972) for determining genetic distances was used. Genetic distance measures the time that has elapsed since populations were genetically equivalent.

The Dendrogram is based on Nei's (1972) using Genetic distance: Method = UPGMA (computer software), modified from NEIGHBOR procedure of PHYLIP Version 3.5.

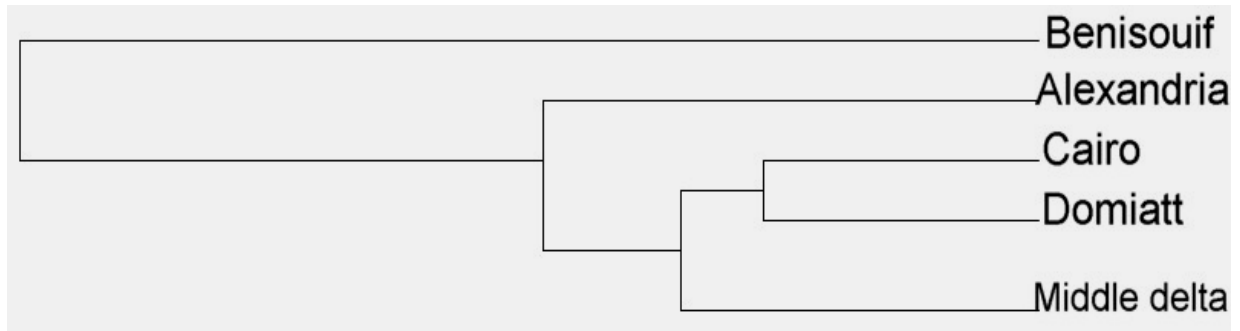

Dendrogram (1) is showing the genetic relationship between the different populations using Ds genetic distance obtained from the 4 microsatellites markers analyzed. It indicates the expected phylogeny tree for the divergence of the different populations from each other.

The populations of Domiatta and Cairo showed the lowest divergence whereas; the greatest differentiation was detected between Beni Souif and other populations.

The dendogram is giving a primary idea about the possible migration way across Egypt. It is showing that the migration started from the northern east part of Egypt (Domiatt) to the middle delta then to Cairo and Beni Souif regions. Alexandria took also a part of migration through it. This dendogram gives a logic estimate for the migration process which happened in the past. Only one confliction will be noted. It was the genetic distance between Domiatt and Cairo (0.0706) which was less than that between Domiatt and Middle delta (0.0828).This may be due to the low number of markers studied.

The Nei genetic analysis is presented in Tables 7,8 .

Table 7. Nei's genetic identity (above diagonal) and genetic distance (below diagonal)

\begin{tabular}{cccccc}
\hline & $\begin{array}{c}\text { Beni } \\
\text { Souif }\end{array}$ & Alexandria & Cairo & $\begin{array}{c}\text { Middle } \\
\text { Delta }\end{array}$ & Domiatt \\
\hline Beni Souif & $* * * *$ & 0.7836 & 0.7980 & 0.6591 & 0.7224 \\
Alexandria & 0.2257 & $* * * *$ & 0.9127 & 0.8020 & 0.8753 \\
Cairo area & 0.2256 & 0.0881 & $* * * *$ & 0.9141 & 0.9318 \\
Middle Delta & $\mathbf{0 . 4 1 6 9}$ & 0.2207 & 0.0899 & $* * * *$ & 0.9205 \\
Domiatt & 0.3251 & 0.1331 & $\mathbf{0 . 0 7 0 6}$ & 0.0828 & $* * * *$ \\
\hline
\end{tabular}


The lowest genetic distance was found between Cairo- Domiatt pair (0.0706) and the highest genetic distance between the middle delta- Beni Souif pair (0.4169) were significantly different from zero $(p<0.05)$ for all pairwise combination.

Table 8. Estimated divergence time of the populations under study on the basis of the 4 microsatellite loci studied

\begin{tabular}{lcccc}
\hline Population & $\begin{array}{l}\text { Nei's } \\
\text { standard } \\
\text { genetic } \\
\text { distance } \\
(\mathbf{D s})\end{array}$ & $\begin{array}{c}\text { Mutation } \\
\text { rate } \\
(\boldsymbol{\alpha})\end{array}$ & Divergence time & \\
\hline Beni Souif \& Great Cairo & 0.226 & $1.2 \times 10^{-3}$ & 94 & Years \\
Beni Souif \& Alexandria & 0.246 & & 101 & 808 \\
Beni Souif \& Middle delta & 0.417 & & 174 & $\mathbf{1 3 9 2}$ \\
Beni Souif \& Domiatt & 0.325 & & 135 & 1080 \\
Great Cairo \& Alexandria & 0.088 & & 36.7 & 293 \\
Great Cairo \& Middle & 0.089 & & 37 & 296 \\
delta & 0.071 & & 29 & $\mathbf{2 3 2}$ \\
Great Cairo \& Domiatt & 0.221 & & 52 & 736 \\
Alexandria \& Middle delta & 0.133 & & 34 & 272 \\
Alexandria \& Domiatt & 0.083 & & & \\
Middle delta \& Domiatt & & & & \\
\hline
\end{tabular}

Taking into consideration that one generation equals eight years, and transforming the number of generations into years.

Looking at the table we could notice that the biggest divergence time (1392 years) was between the Beni Souif and Middle delta cattle, in contrast the lowest divergence time (232 years) was between Cairo and Domiatt. Other divergence was between these two values. The results of this table are confirming the phylogeny dendrogram obtained using UPGMA method.

The results in general gave an evidence that all Baladi cattle raised in Egypt have genetic similarities, and could be considered as a one breed. This does not agree with FAO (1993), which reported that Egyptian cattle have many breeds. The variations in productivity of some populations especially between Domiatt and Saidi, may be due to environmental or management factors. However, it should be noticed that the present study should be repeated on larger numbers of animals. The FAO report (FAO, 1998) recommended that at least 25 animals (if closely related up to 50 individuals) from each breed is assayed with 25-30 microsatellite markers.

\section{REFERENCES}

Bostein, D., R.L. White, M. Skolnick and R.W. Davis, 1980. Construction of genetic linkage maps in man using restriction fragment length polymorphism. Am. J. Hum. Genet. 32: 314-331.

Canon, J., P. Alexandrino, I. Bessa, C. Carleos and Y. Carretero, 2001. Genetic diversity measures of local European beef cattle breeds for conservation purposes. Genet. Sel. Evol. 33: 311-332.

Edwards, C.J., C. Gaillard, D.G. Bradley and D.E. MacHugh, 2000. Y-specific microsatellite in a range of bovid species. Animal Genetics 31:127-130. 
FAO, 1993. Food and Agriculture Organization of the United Nations, Rome. Breed database, Map Manager, http://dad.fao.org/en/Home.htm.

FAO, 1998. Food and Agriculture Organization of the United Nations, Rome: Secondary Guidelines for Development of National Farm Animal Genetic Resources Management Plans. Measurement of Domestic Animal Diversity (MoDAD): Original Working Group Report. http://dad.fao.org/en/refer/library/ guidelin/workgrp.pdf

Fries, R., A. Eggen and G. Stranzinger, 1990. The bovine genome contains polymorphic microsatellites. Genomics, 8(2):403-406.

Goudet, J., 2002. FSTAT Computer Package for PCs. Institute of Ecology, UNIL, Lausanne, Switzerland.

Ibeagha-Awemu, E. M., O.C. Jann, C. Weimann and G. Erhardt, 2004. Genetic diversity, introgression and relationships among West/Central African cattle breeds. Genet. Sel. Evol. 36(6):673-690.

Kaukinen, J. and S.L. Varvio, 1993. Eight polymorphic bovine microsatellites. Anim. Genet., 24: 148.

Kimura, M. and J.F. Crow, 1964. The number of alleles that can be maintained in a finite population. Genetics 68: 47.

Loftus R. T., O. Ertugrul, A. H. Harba, M.A.A. El-Barody, D.E. MacHugh, D.G. Bradley, 1999. A microsatellite survey of cattle from a centre of origin: the Near East. Mol Ecol 8: 2015-2022.

Loftus, R. T., O. Ertugrul, A.H. Harba, M.A. El-Barody, D.E. MacHugh, S.D. Park and D.G. Bradley, 2002. A microsatellite survey of cattle from a centre of origin: the Near East. Mol Ecol. 8(12):2015-2022.

Lubieniecka, J., G. Grzybowski and K. Lubieniecki, 2001. Genetic variation in nine European cattle breeds as determined on the basis of microsatellite markers. I. Within-breed variation. Animal Science Papers and Reports 19 (4): 249-264.

Machado, A.M., I. Schuster, L.L Martinez and A.L. Campos, 2003. Genetic diversity of four cattle breeds using microsatellite markers. R. Bras. Zootec. 32(1): 93-98.

McHugh, D. E., R.T. Loftus, P. Cunningham and D.G. Bradley, 1998. Genetic structure of seven European cattle breeds assessed using 20 microsatellite markers. Anim. Genet., 29, 333-340.

Moioli, B., A. Georgoudis, F. Napolitano, G. Catillo, E. Giubilei, Ch. Ligda and M. Hassanane, 2001. Genetic diversity between Italian, Greek and Egyptian buffalo populations. Livestock Production Science, 7(3): 203-211.

Morsy, M. A., 1980. Dairy cattle management. Cairo University publishing.

Nei, M., 1972. Genetic distance between populations. Am. Nat. 106: 283-292.

Nei, M., F. Tajima and Y. Tateno, 1983. Accuracy of estimated phylogenetic trees from molecular data. J. Mol. Evol. 19: 153-170.

Sambrook, J., E.F. Fritsch and T. Maniatis, 1989. Molecular Cloning-A Laboratory Manual, Cold Spring Harbor Laboratory Press.

Slatkin, M., 1985. Gene flow in natural populations. Ann. Rev. Ecol. Syst. 16: 393430.

Steffen, P., A. Eggen, A.B. Dietz, J.E. Womack, G. Stranzinger and R. Fries, 1993. Isolation and mapping of polymorphic microsatellites in cattle. Anim. Genet., 24(2):121-124.

Vaiman, D., D. Mercier, K. Moazami-Goudarzi, A. Eggen, R. Ciampolini, A. Lepingle, R. Velmala, J. Kaukinen, S.L. Varvio and P. Martin, 1994. A set of 99 
cattle microsatellites: characterization, synteny mapping, and polymorphism. Mamm. Genome, 5(5):288-297.

Weir, B. S., 1990. Genetic Data Analysis. Sinauer, Sunderland. MA.

Weir, B.S. and C.C. Cockerham, 1984. Estimating F-statistics for the analysis of population structure. Evolution 38: 1358-1370.

Wright, S., 1951. The genetic structure of populations. Ann. Eugen. 15: 323-354.

Wright, S., 1978. Evolution and the genetics of population. Variability Within and Among Natural Population, vol. 4. University of Chicago Press, Chicago, IL.

Yeh, F.C., T. Boyle, Y. Rongcai, Z. Ye and J.M. Xian, 1999. POPGENE, Version 1.31. A Microsoft Window Based Free Ware for Population Genetic Analysis. University of Alberta, Edmonton. 
دراسة التباين الوراثى في الأبقار المصرية باستخدام التوابع الوراثية الاقيقة

محمد صابر حسانين1، حسن ممدوح العشماوى1، سهير عبد القوى عبد الباسط، 2 محمد منير شعبان مبروك صابر، زينب جابر عبد الحميد 1

1ـ قسم بيولوجيا الخلية، المركز القومي للبحوث، 2- قسم علم الحيوان، كلية العلوم (فرع البنات)، جامعة الأزهر، 3ـ قسم الإتتاج الحيو اني، كلية الزراعة، جامعة الأزهر

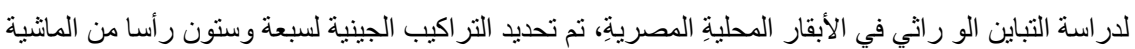

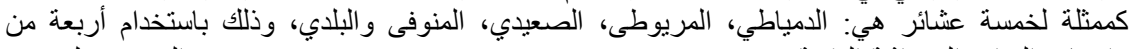

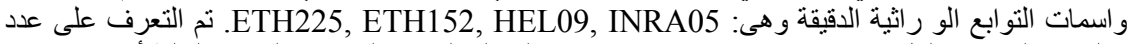

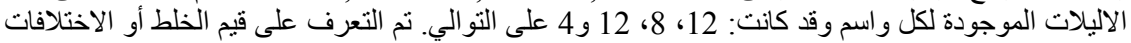

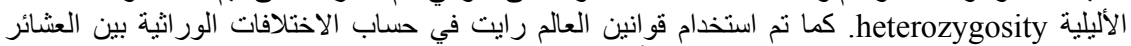

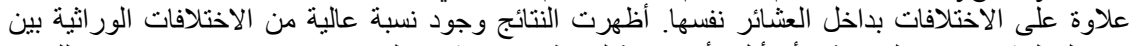

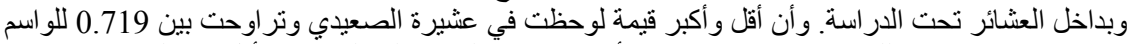

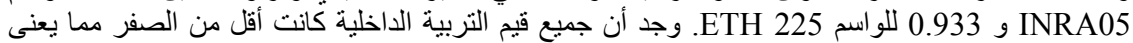

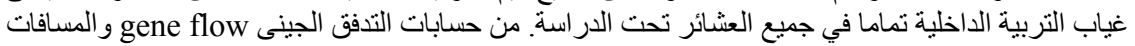

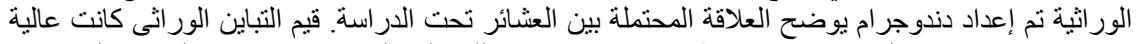

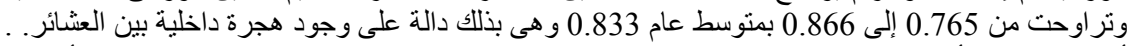

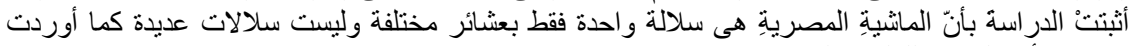

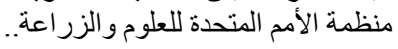

